\title{
PEMBUATAN SABUN TRANSPARAN BERBASIS MINYAK KELAPA DENGAN PENAMBAHAN EKSTRAK BUAH MENGKUDU (Morinda citrifolia) SEBAGAI BAHAN ANTIOKSIDAN
}

\author{
MAKING OF COCONUT OIL BASED TRANSPARENT SOAP WITH ADDITION \\ OF NONI FRUIT EXTRACT (Morinda citrifolia) AS AN ANTIOXIDANT AGENT
}

\author{
Lilis Sukeksi, Meirany Sianturi, Lionardo Setiawan \\ Departemen Teknik Kimia, Fakultas Teknik, Universitas Sumatera Utara, \\ Jalan Almamater, Medan, 20155, Indonesia \\ Email: lilissukeksi79@yahoo.com
}

\begin{abstract}
Abstrak
Penelitian ini bertujuan mengkaji pengaruh konsentrasi alkali dan mengkudu terhadap produk sabun yang terbentuk. Penelitian ini diawali dengan pengambilan ekstrak mengkudu dengan proses maserasi menggunakan etanol. Kemudian dilakukan pembuatan sabun padat transparan pada proses saponifikasi dengan variabel tetap volume minyak $70 \mathrm{ml}$, suhu reaksi $80^{\circ} \mathrm{C}$ dan waktu pengadukan 60 menit. Sedangkan untuk variabel bebasnya konsentrasi larutan alkali 26\%, 28\%, $30 \%$, 32\%, jumlah mengkudu 0 g, 10 g, 20 g, 30 g. Respon yang diamati adalah kadar air, Keasaman $(\mathrm{pH})$, bilangan penyabunan, alkali bebas, asam lemak bebas, stabilitas busa, tegangan permukaan dan aktivitas antioksidan. Hasil yang terbaik diperoleh pada konsentrasi alkali $26 \%$ dan jumlah ekstrak mengkudu $30 \mathrm{~g}$ dengan kadar air 24,10\%, kadar alkali bebas 0\%, pH 9,0, kadar asam lemak bebas $0,48 \%$, bilangan penyabunan $200 \mathrm{mg} / \mathrm{g}$, tegangan permukaan $29,70 \mathrm{dyne} / \mathrm{cm}$, stabilitas busa $63 \%$ dan aktivitas antioksidan sebesar $153,850 \mu \mathrm{g} / \mu \mathrm{L}$.
\end{abstract}

Kata kunci: antioksidan, mengkudu, sabun transparan, saponifikasi, tegangan permukaan

\begin{abstract}
The purpose of this study is to examine the effect of alkali concentration and the amount of added morinda citrifolia toward the formed of soap product. This study begins with maserating the noni fruit with ethanol. Then the making of transparent solid soap was made in the saponification process with a fixed variable oil volume of $70 \mathrm{ml}$, reaction temperature of $80^{\circ} \mathrm{C}$ and stirring time of 60 minutes. Whereas for the independent variables alkaline solution concentrations were $26 \%$, $28 \%, 30 \%, 32 \%$, the amount of noni extract $0 \mathrm{~g}, 10 \mathrm{~g}, 20 \mathrm{~g}, 30 \mathrm{~g}$. The responses observed were water content, acidity $(\mathrm{pH})$, saponification number, free alkali, free fatty acid, foam stability, surface tension and antioxidant activity. The best results were obtained at $26 \%$ alkaline concentration and $30 \mathrm{~g}$ of noni extract with a moisture content of 24,10\%, $0 \%$ free alkali content, pH 9,0, free fatty acid content 0,480\%, saponification $200 \mathrm{mg} / \mathrm{g}$, surface tension 29,70 dyne $/ \mathrm{cm}$, foam stability $81 \%$ and antioxidant activity of $153,850 \mu \mathrm{g} / \mu \mathrm{L}$.
\end{abstract}

Keywords: antioxidant, noni fruit, transparent soap, saponification, surface tension

\section{Pendahuluan}

Sabun merupakan bahan yang berfungsi membersihkan kotoran dan bakteri dari kulit. Dewasa ini, pemanfaatan sabun sebagai pembersih kulit semakin meningkat dan beragam. Keragaman sabun yang dijual secara komersial terlihat pada jenis, wangi, warna dan manfaat yang ditawarkan [1]. Proses pembuatan sabun dengan reaksi saponifikasi terbagi menjadi dua yaitu proses panas dan proses dingin. Perbedaan kedua proses tersebut yaitu sabun yang dibuat dengan proses dingin dilakukan pada suhu kamar atau tanpa disertai pemanasan, sedangkan proses panas melibatkan reaksi saponifikasi dengan panas yang dilakukan pada suhu $70-80^{\circ} \mathrm{C}[3]$.

Sabun mandi dibagi menjadi dua jenis yaitu sabun cair dan sabun padat. Sabun padat terdiri dari 3 jenis yaitu sabun opaque, translucent dan transparan. Sabun opaque (sabun padat biasa) adalah sabun yang digunakan sehari-hari, sabun translusen adalah sabun yang sifatnya berada diantara sabun opaque dan trasparan, sedangkan sabun transparan adalah sabun yang sering digunakan untuk sabun kecantikan wajah dan sabun kesehatan kulit [7]. 
Kemampuan utama sabun padat transparan sebagai pembersih tidak cukup membuatnya menarik dari segi pemasaran apabila tidak disertai manfaat yang lebih spesifik. Oleh sebab itu, dibutuhkan bahan aktif yang mampu memberikan manfaat ganda pada sabun transparan selain zat pembersih yang bisa berfungsi sebagai penangkal radikal bebas dan mencegah infeksi bakteri maupun mikroba [9]. Salah satu bahan yang memiliki khasiat antibakteri dan antioksidan yaitu ekstrak buah mengkudu.

Mengkudu termasuk tumbuhan keluarga kopi-kopian (Rubiaceae), yang mulanya berasal dari wilayah daratan Asia Tenggara. Setelah lunak, daging buah mengkudu banyak mengandung air yang aromanya tidak sedap. Bau itu timbul karena pencampuran antar asam kaprik dan asam kaproat. Kedua senyawa tersebut bersifat aktif sebagai antibiotik [2].

Kandungan nutrisi yang terkandung dalam buah mengkudu adalah protein, mineral, vitamin $\mathrm{C}$ dan asam lemak rantai pendek. Kadar vitamin C pada buah mengkudu yaitu 12, 24\%. Buah mengkudu menghasilkan sederatan antioksidan diantaranya: scopoletin, nitric oxide, vitamin C dan vitamin A [10].

\section{Teori}

Sabun merupakan senyawa natrium atau kalium dengan asam lemak dari minyak nabati atau lemak hewani bebentuk padat, lunak atau cair, dan berbusa. Sabun dihasilkan oleh proses saponifikasi, yaitu hidrolisis lemak menjadi asam lemak dan gliserol dalam kondisi basa. Pembuat kondisi basa yang biasa digunakan adalah Natrium Hidroksida $(\mathrm{NaOH})$ dan Kalium Hidroksida $(\mathrm{KOH})$. Jika basa yang digunakan adalah $\mathrm{NaOH}$, maka produk reaksi berupa sabun keras (padat), sedangkan basa yang digunakan adalah $\mathrm{KOH}$, maka produk reaski berupa sabun cair [9].

Sabun dapat dibuat dari reaksi saponifikasi yaitu pemutusan rantai trigliserida melalui reaksi dengan alkali yang akan menghasilkan produk utama sabun dan produk samping berupa gliserol [5].

Sabun padat transparan adalah sabun yang berbentuk batangan dengan tampilan transparan, menghasilkan busa lebih lembut di kulit dan penampakannya lebih berkilau dibandingkan jenis sabun lainnya. Sabun transparan sering disebut sebagai sabun gliserin, karena pada proses pembuatan sabun transparan ditambahkan sekitar 10-15 \% gliserin. Tampilan sabun transparan yang menarik mewah dan berkelas menyebabkan sabun transparan dijual dengan harga yang relatif lebih mahal [13]. Sabun mandi transparan adalah salah satu produk inovasi sabun yang menjadikan sabun menjadi lebih menarik. Sabun transparan mempunyai busa yang lebih halus dibandingkan dengan sabun opaque (sabun yang tidak transparan).

Sabun transparan merupakan sabun yang memiliki tingkat transparansi paling tinggi. Sabun jenis ini memancarkan cahaya yang menyebar dalam partikel-partikel kecil, sehinga obyek yang berada diluar sabun akan kelihatan jelas (tembus pandang) [12]. Faktor yang dapat mempengaruhi transparansi sabun adalah kandungan alkohol, gula, dan gliserin dalam sabun. Ketika sabun akan dibuat jernih dan bening, maka hal yang paling penting adalah kualitas gula, alkohol, dan gliserin. Kandungan gliserin baik untuk kulit karena berfungsi sebagai pelembab pada kulit dan membentuk fasa gel pada sabun [8].

Dalam pembuatan sabun, ada beberapa faktor yang harus diperhatikan. Adapun faktor factor yang mempengaruhi proses pembuatan sabun adalah [11]:

1. Konsentrasi larutan Alkali

Konsentrasi alakali yang digunakan dihitung berdasarkan stokiometri reaksi, dimana penambahan minyak harus sedikir berlebih agar sabun yang terbentuk tidak memiliki nilai alkali bebas berlebih. Alkali terlalu pekat akan menyebabkan terpecahnya emulsi pada larutan sehingga fasenya tidak homogen, sedangkan jika alkali yang digunakan terlalu encer, maka reaksi akan membutuhkan waktu yang lebih lama.

2. Suhu

Ditinjau dari segi termodinamikan, kenaikan suhu akan menurunkan rendemen sabun, hal ini dapat dilihat dari persamaan (1) berikut:

$$
\frac{\mathrm{d} \ln \mathrm{K}}{\mathrm{dT}}=\frac{\Delta \mathrm{H}}{\mathrm{RT}}
$$

Karena reaksi penyabunan merupakan reaksi eksotermis ( $\Delta \mathrm{H}$ negatif), maka dengan kenaikan suhu akan dapat memperkecil harga $\mathrm{K}$ (konstanta keseimbangan), tetapi jika ditinjau dari segi kinetika, kenaikan suhu akan menaikan kecepatan reaksi.

3. Pengadukan

Pengadukan dilakukan untuk memperbesar probobalitas interaksi molekul-molekul reaktan yang bereaksi. Jika interaksi antar molekul reaktan semakin besar, maka kemungkinan terjadinya reaksi semakin besar pula. Hal ini sesuai dengan persamaan Arhenius dimana konstanta kecepatan reaksi $\mathrm{k}$ akan semakin besar dengan semakin sering terjadinya interaksi yang disimbolkan dengan konstanta A.

4. Waktu 
Semakin lama waktu reaksi menyebabkan semakin banyak pula minyak yang dapat tersabunkan, berarti hasil yang didapat juga semakin tinggi, tetapi jika reaksi telah mencapai kondisi setimbangnya, penambahan waktu tidak akan meningkatkan jumlah minyak yang tersabunkan [4].

\section{Metodologi Penelitian \\ Bahan Baku dan Peralatan}

Bahan yang digunakan dalam penelitian ini adalah minyak kelapa, minyak jarak, Aquadest, Asam Klorida, Asam Stearat, Asam Sitrat, indikator Phenolphthalein, Natrium Hidroksida dan Etanol, gula pasir, mengkudu, Gliserin, pewarna dan pewangi.

Alat yang digunakan meliputi neraca elektrik, beaker glass, Erlenmeyer, thermometer, oven,aluminium foil, magnetik Stirrer, gelas ukur, Stopwatch, spatula, pipet tetes, buret, statif dan klem, pH meter, hotplate.

\section{Prosedur Saponifikasi}

Proses saponifikasi diawali dengan memanaskan minyak kelapa dan minyak jarak hingga suhu $50^{\circ} \mathrm{C}$, kemudian direaksikan dengan larutan $\mathrm{NaOH}$, dipanaskan menggunakan hotplate dan diaduk dengan magnetic stirrer. Setelah itu ditambahkan asam stearat sedikit demi sedikit. Kemudian setiap \pm 5 menit diberikan penambahan etanol, gliserol, larutan gula dan asam sitrat. Setelah sabun dasar selesai dibuat, dilakukan penambahan lidah buaya sesuai dengan variabel yang ditentukan. Proses saponifikasi dilanjutkan hingga campuran menjadi homogen seluruhnya.

\section{Analisa Tegangan Permukaan}

Pengujian ini dilakukan dengan menggunakan Tensiometer Du Nouy. Wadah yang digunakan yaitu gelas piala berukuran 250 $\mathrm{ml}$. Sebelum digunakan, cincin dibilas terlebih dahulu dengan aquadest, lalu dikeringkan. Cincin platinum dicelupkan ke akuades. Posisi alat diatur supaya horizontal dengan water pass dan diletakkan pada tempat yang bebas getaran, angin, sinar matahari, dan panas. Larutan sampel (sabun $10 \%$ dalam aquadest) dimasukkan ke gelas piala dan diletakkan di atas dudukan (plateform) pada Tensiometer Du Nouy. Cincin platinum dimasukkan ke larutan sampel tersebut dengan cara menaikkan dudukan sampai skala vernier Tensiometer Du Nouy diatur pada posisi nol dan jarum penunjuk berada pada posisi berimpit dengan skala kaca.

Proses ini diteruskan sampai film cairan tepat lepas dari cincin. Skala dibaca dan dicatat sebagai tegangan permukaan pada saat lapisan surfaktan lepas dari cincin.

Perhitungan penurunan tegangan permukaan (PTP) dapat dihitung menggunakan rumus [11].

$$
\mathrm{PTP}=\mathrm{X}-\mathrm{Y} \text {. }
$$

Keterangan:

$\mathrm{X}=$ Tegangan permukaan air

$\mathrm{Y}=$ Tegangan permukaan larutan sabun $10 \%$

\section{Analisa Aktivitas Antioksidan}

Analisa aktivitas antioksidan dilakukan dengan metode DPPH tahap awal pengujiannya adalah pembuatan larutan DPPH $0,4 \mathrm{mM}$, pembuatan larutan blanko dan larutan uji sebesar 5, 10, 25, 50 dan 100 ppm. Semua sampel dihomogenkan dan diinkubasi pada suhu $37^{\circ} \mathrm{C}$ selama 30 menit kemudian diukur serapannya menggunakan spektrofotometer UV-Vis dengan panjang gelombang $517 \mathrm{~nm}$. Aktivitas antioksidan dihitung dengan rumus:

$$
\% \text { hambatan }=\frac{\mathrm{B}-\mathrm{A}}{\mathrm{B}} \times 100 \%
$$

Keterangan:

$\mathrm{A}=$ serapan pada sampel

$\mathrm{B}=$ serapan pada blanko

Nilai IC $_{50}$ dihitung menggunakan persamaan regresi linear dari grafik dengan $\mathrm{y}=\mathrm{a}+\mathrm{bx}$, dengan sumbu $\mathrm{x}$ adalah konsentrasi larutan uji dan y adalah \%IC atau \% hambatan [6].

\section{Hasil dan Pembahasan \\ Penentuan Konsentrasi Larutan Gula}

Penelitian ini dilakukan untuk menentukan konsentrasi larutan gula yang mampu memberikan struktur transparan terbaik. Dalam penelitian ini dilakukan pembuatan sabun transparan tanpa bahan aditif dengan variasi konsentrasi larutan gula sebesar 25\%, 40\%, 55\% dan $70 \%$. Berikut merupakan foto sabun transparan yang dihasilkan.

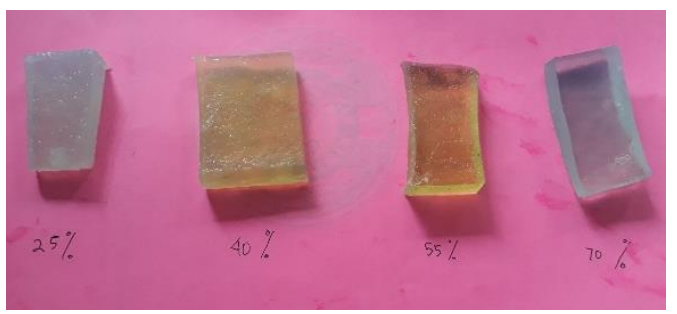

Gambar 1. Pembuatan Sabun Transparan dengan Variasi Konsentrasi Larutan Gula

Dari gambar 1 dapat dilihat adanya pengaruh perbedaan konsentrasi larutan gula yang diberikan dengan ketransparanan sabun. 
Berdasarkan hasil penelitian diperoleh struktur transparan tertinggi pada konsentrasi larutan gula sebesar $70 \%$. Hal ini sesuai dengan teori yang ada dimana larutan gula mampu membentuk struktur kristal dalam sabun sehingga cahaya yang terlewatkan menjadi lebih banyak.

\section{Analisa Kadar Alkali Bebas}

Alkali bebas merupakan alkali yang terdapat dalam contoh sabun, tetapi tidak terikat sebagai senyawa sabun. Menurut SNI, kadar alkali bebas maksimal $0,1 \%$ untuk $\mathrm{NaOH}$ dan $0,14 \%$ untuk $\mathrm{KOH}$. Kadar alkali bebas tidak boleh terlalu tinggi karena dapat menyebabkan iritasi pada kulit pada saat digunakan.

Dalam penelitian ini, tidak ditemukan kadar alkali bebas pada sabun transparan setelah penyimpana setelah 2 minggu. Hal ini ditandai dengan tidak terbentuknya warna merah muda pada saat larutan sampel ditetesi dengan indikator phenolphthalein. Hal ini dapat dikarenakan terjadinya penetralan pada buah mengkudu yang bersifat asam oleh $\mathrm{NaOH}$. Selain itu, adanya penggunaan bahan tambahan lain yang bersifat asam seperti asam sitrat dan asam stearat juga menyebabkan terjadinya penetralan oleh $\mathrm{NaOH}$ sehingga jumlah alkali yang dibutuhkan untuk penyabunan menjadi berkurang.

\section{Analisa Kadar Air}

Berikut grafik yang menunjukkan pengaruh variasi konsentrasi larutan alkali dan jumlah mengkudu terhadap kadar air sabun transparan.

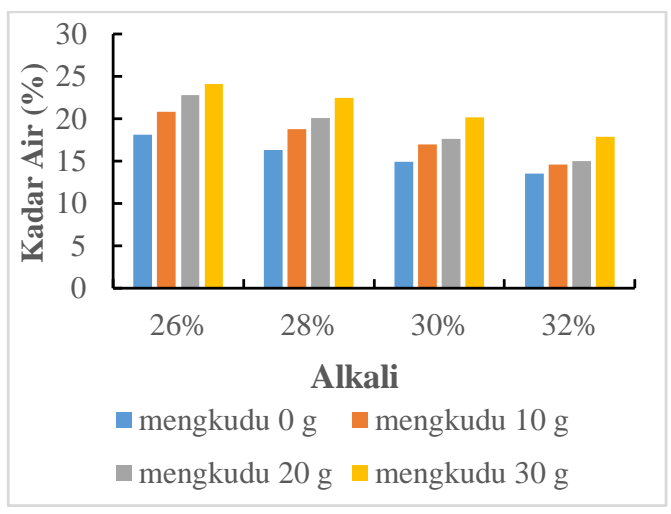

Gambar 2. Grafik Pengaruh Konsentrasi Larutan Alkali dan Jumlah Buah Mengkudu terhadap Kadar Air

Pada penelitian ini, hasil kadar air tanpa penambahan mengkudu sebagai bahan antioksidan pada sabun transparan yang diperoleh lebih rendah dibandingkan dengan sabun dengan penambahan mengkudu sebagai antioksidan. Adanya peningkatan kadar air ini menunjukkan bahwa penambahan buah mengkudu berpengaruh terhadap kenaikan kadar air. Hal ini karena antioksidan mengandung air sehingga menambah antioksidan berarti memberikan tambahan kandungan air pada sabun transparan tersebut. Buah mengkudu memiliki daging buah yang banyak mengandung air yang aromanya seperti buah busuk.

Berdasarkan hasil uji, kadar air semakin menurun seiring dengan meningkatnya konsentrasi $\mathrm{NaOH}$ yang digunakan pada pembuatan sabun. Hal ini karena semakin tinggi konsentrasi $\mathrm{NaOH}$, maka air yang ditambahkan semakin sedikit.

\section{Analisa Derajat Keasaman (pH)}

Berikut grafik yang menunjukkan pengaruh variasi konsentrasi larutan alkali dan penambahan mengkudu terhadap $\mathrm{pH}$ sabun transparan.

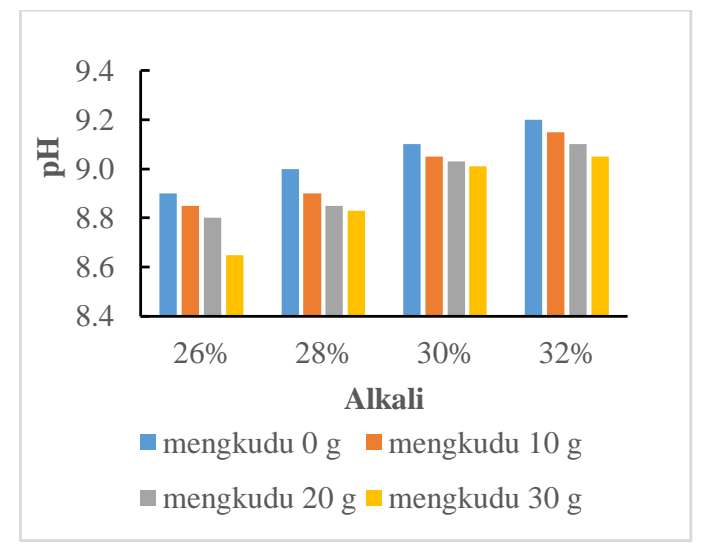

Gambar 3. Grafik Pengaruh Konsentrasi Larutan Alkali dan Jumlah Mengkudu terhadap pH Sabun Transparan

Berdasarkan hasil analisis, diperoleh nilai $\mathrm{pH}$ sabun cenderung menurun seiring dengan bertambahnya konsentrasi ekstrak mengkudu yang digunakan dan meningkat seiring dengan bertambahnya konsentrasi NaOH. Menurut SNI standar $\mathrm{pH}$ sabun padat antara $9-11$. Sedangkan pH kulit manusia yaitu 4,5-7 dan sebaiknya produk kesehatan kulit mendekati $\mathrm{pH}$ kulit [9]. Nilai pH sabun transparan yang diperoleh pada penelitian ini berkisar antara 8,6-9,2. Dengan demikian nilai $\mathrm{pH}$ semua sabun hasil penelitian telah sesuai standar SNI. Nilai pH sabun yang optimum pada penelitian ini adalah sampel dengan kandungan mengkudu 30 gr dan dengan konsentrasi alkali $26 \%$ karena $\mathrm{pH}$ yang dihasilkan 8,6 dimana $\mathrm{pH}$ tersebut mendekati $\mathrm{pH}$ kulit sehingga sesuai dengan kesehatan kulit 
dikarenakan kandungan asam pada mengkudu yang dapat menurunkan $\mathrm{pH}$.

\section{Analisa Kadar Asam Lemak Bebas}

Berikut grafik yang menunjukkan pengaruh variasi konsentrasi larutan alkali dan penambahan mengkudu terhadap kadar asam lemak bebas sabun transparan.

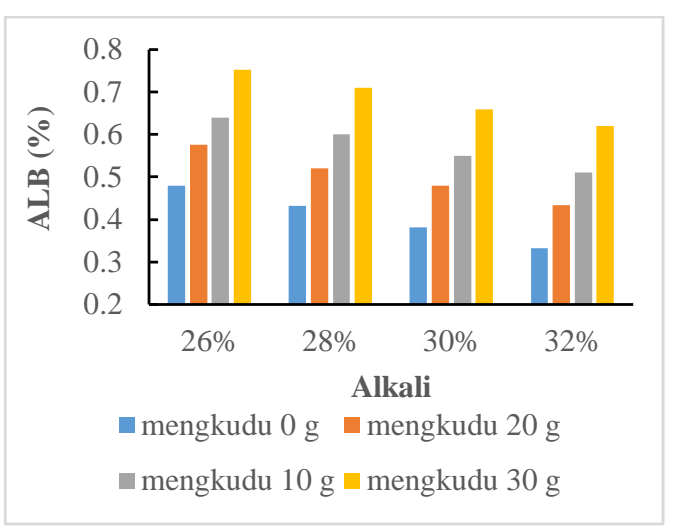

Gambar 4. Grafik Pengaruh Variasi Konsentrasi Larutan Alkali dan Jumlah Mengkudu terhadap Kadar Asam Lemak Bebas Sabun Transparan

Dari gambar 4 dapat dilihat Hasil uji sabun menunjukkan bahwa kadar asam lemak bebas pada sabun transparan berada pada angka 0,332 - $0,752 \%$ sehingga dapat disimpulkan bahwa kadar asam lemak pada semua sabun yang dihasilkan telah memenuhi SNI. Kadar asam lemak bebas juga menurun seiring dengan pertambahan buah mengkudu, hal ini disebabkan oleh adanya vitamin $\mathrm{C}$ yang terkandung dalam buah mengkudu yang mampu menetralisir atau menstabilkan senyawa asam lemak bebas. Penyebab lainnya adanya proses adsorbasi fisik pada buah mengkudu yang memiliki luas permukaan dan pori-pori yang besar sehingga mengikat dan menyerap senyawa asam lemak bebas pada permukaannya [10]. Penurunan kadar asam lemak bebas juga diakibatkan lamanya penyimpanan sehingga asam lemak bebas yang terkandung berkurang.

\section{Analisa Stabilitas Busa}

Busa adalah gas yang terjebak oleh lapisan tipis cairan yang mengandung sejumlah molekul sabun yang terabsorpsi pada lapisan tipis tersebut, dalam gelembung, gugus hibrofobik surfaktan akan mengarah ke gas, sedangkan bagian hidrofiliknya akan mengarah ke larutan lalu gelembung akan keluar dari badan cairan. Stabilitas busa adalah kemampuan suatu bahan penghasil busa untuk mempertahankan busa yang dihasilkannya [3].
Berikut pada gambar 5 ditunjukkan pengaruh variasi konsentrasi larutan alkali dan penambahan mengkudu terhadap stabilitas busa sabun transparan:

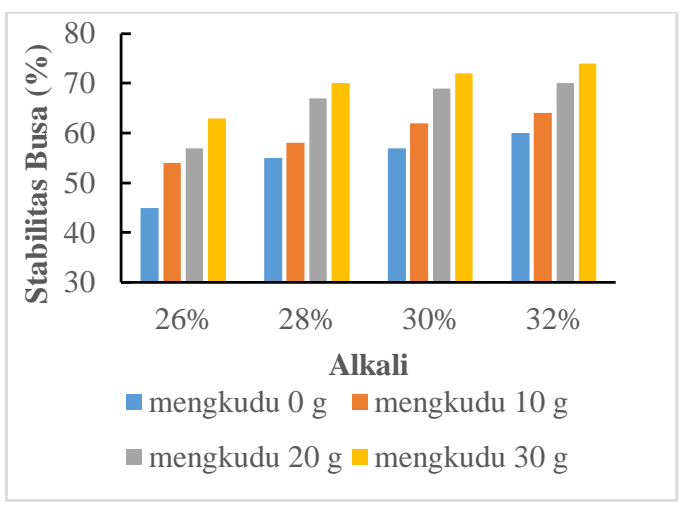

Gambar 5. Grafik Pengaruh Variasi Konsentrasi Larutan Alkali dan Jumlah Mengkudu terhadap Stabilitas Busa Sabun Transparan

Hasil penelitian menunjukkan bahwa jumlah ekstrak mengkudu yang ditambahkan pada sabun transparan tidak menunjukkan perbedaan yang nyata pada nilai persentasi kestabilan busa. Sabun menghasilkan persentase busa yang meningkat karena kandungan saponin pada mengkudu. Menurut penelitian yang dilakukan oleh Cahyani, dkk., (2013) dinyatakan bahwa ekstrak buah mengkudu mengandung sedikit saponin. Saponin merupakan salah satu senyawa metabolit sekunder yang bersifat seperti sabun sehingga saponin disebut sebagai surfaktan alami [7]. Hasil penelitian yang dilakukan menunjukkan bahwa penambahan antioksidan pada sabun transparan yang berasal dari ekstrak yang mengandung saponin menghasilkan kestabilan busa yang meningkat.

\section{Analisa Tegangan Permukaan}

Pada gambar 6 dapat dilihat adanya pengaruh variasi konsentrasi larutan alkali terhadap tegangan permukaan sabun transparan pada penambahan mengkudu $30 \mathrm{~g}$. Berdasarkan hasil penelitian didapatkan bahwa semakin tinggi konsentrasi alkali yang digunakan maka semakin rendah tegangan permukaan sabun transparan yang dihasilkan.

Tegangan permukaan air tanpa campuran sabun sebsar 58,35 dyne/cm [4]. Tegangan permukaan yang telah ditambahkan sabun berkisar antara 29 - 29,7 dyne/cm. Tegangan permukaan sabun cenderung menurun seiring dengan penambahan ekstrak mengkudu sebagai antioksidan. Hal ini menunjukkan bahwa sabun dengan penambahan ekstrak mengkudu memiliki 
kemampuan menurunkan tegangan permukaan sabun.

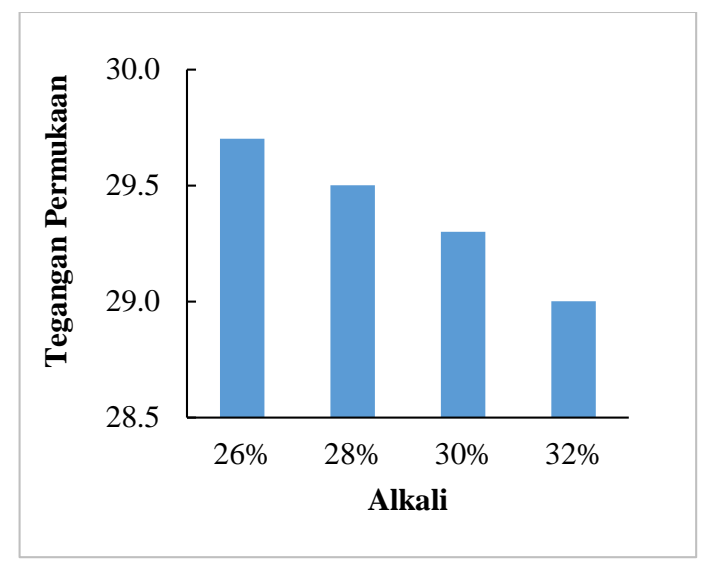

Gambar 6. Grafik Pengaruh Variasi Konsentrasi Larutan Alkali terhadap Tegangan Permukaan pada Penambahan Mengkudu $30 \mathrm{~g}$

\section{Analisa Bilangan Penyabunan}

Berikut grafik yang menunjukkan pengaruh variasi konsentrasi larutan alkali dan jumlah mengkudu terhadap bilangan penyabunan.

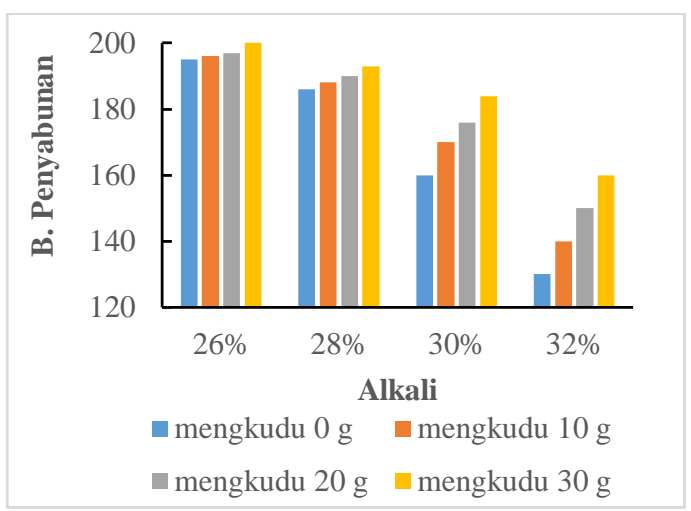

Gambar 7. Grafik Pengaruh Variasi Konsentrasi Larutan Alkali dan Jumlah Mengkudu terhadap Bilangan Penyabunan Sabun Transparan

Berdasarkan grafik diatas, bilangan penyabunan pada perlakuan $\mathrm{NaOH} 26 \%, 28 \%$, $30 \%$ dan $32 \%$ sangat bervariasi. Dimana bilangan penyabunan yang paling tinggi diperoleh dari konsentrasi $\mathrm{NaOH} 26 \%$ dengan nilai 110 dan yang terendah pada saat konsentrasi $\mathrm{NaOH} 32 \%$ dengan penambahan mengkudu yaitu bernilai 67 .

Hasil analisis menunjukkan bahwa konsentrasi larutan $\mathrm{NaOH}$ berpengaruh terhadap bilangan penyabunan sabun yang dihasilkan. Namun bilangan penyabunan pada hasil penelitian belum sesuai SNI karena berada dibawah angka 196-206. Hal ini dapat menunjukkan bahwa dibutuhkan peningkatan konsentrasi $\mathrm{NaOH}$ sehingga bilangan penyabunan sabun dapat meningkat.

Berdasarkan penelitian yang dilakukan oleh Samsuni, 2010 didapatkan hasil bahhwa bilangan penyabunan cenderung menurun seiring dengan peningkatan konsentrasi $\mathrm{NaOH}$. Semakin tinggi konsentrasi $\mathrm{NaOH}$ maka asam lemak bebas berkurang pada sabun berkurang sehingga nilai bilangan penyabunan menurun.

\section{Analisa Aktivitas Antioksidan}

Berikut grafik yang menunjukkan hambatan terhadap radikal bebas DPPH oleh sabun transparan:

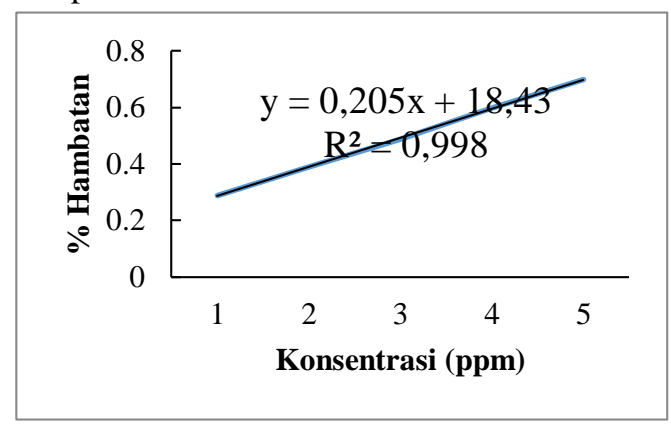

Gambar 8. Grafik Pengaruh Penambahan Mengkudu terhadap Aktivitas Antioksidan pada Sabun Transparan

Dari gambar 8 dapat dilihat adanya pengaruh penambahan mengkudu terhadap radikal bebas DPPH pada sabun transparan. Aktivitas antioksidan adalah kemampuan suatu bahan antioksidan dalam menghambat oksidasi oleh radikal bebas. Dari hasil penelitian didapatkan bahwa semakin tinggi konsentrasi sabun transparan maka hambatan terhadap radikal bebas DPPH semakin tinggi.

$I C_{50}$ adalah konsentrasi yang dibutuhkan untuk menghasilkan penurunan aktivitas DPPH sebesar 50\%. Berdasarkan penelitian sebelumnya, nilai $I C_{50}$ buah mengkudu sebesar $104,73 \pm 4,56 \mu \mathrm{g} / \mathrm{mL}$. Berdasarkan tingkat kekuatan antioksidan, aktivitas antioksidan yang sangat kuat bila $I C_{50}<50 \mu \mathrm{g} / \mathrm{mL}$ dibandingkan dengan ekstrak etanol mengkudu, aktivitas antioksidan buah mengkudu dinyatakan sedang

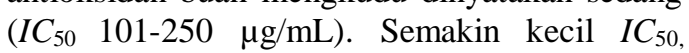
senakin kuat aktivitas antioksidannya [9].

Dari persamaan diatas didapat nilai $I C_{50}$ dari ekstrak megkudu pada sabun transparan sebesar $153,85 \mu \mathrm{g} / \mathrm{mL}$ yang menyatakan bahwa aktivitas antioksidan mengkudu pada sabun tranparan dibandingkan pada ekstrak mengkudu menurun menjadi lemah. Hal ini disebabkan oleh ketidakstabilan flavonoid dalam mengkudu yang ditambahkan ke sabun transparan sebagai hasil 
dari proses pembuatan maupun selama masa penyimpanan.

Flavonoid merupakan senyawa yang memiliki aktivitas antioksidan, namun kurang stabil terhadap paparan suhu diatas $60^{\circ} \mathrm{C}$, sedangkan pada proses penelitian dilaksanan dengan suhu reaksi $70-80^{\circ} \mathrm{C}$ sehingga mengakibatkan kinerja antioksidan melemah.

\section{Kesimpulan}

Kesimpulan yang diperoleh dari penelitian ini adalah:

1. Konsentrasi larutan gula $70 \%$ memberikan struktur ketransparanan terbaik.

2. Pembuatan sabun transparan dengan konsentrasi larutan alkali $30 \%$ dan penambahan ekstrak buah mengkudu sebesar $30 \mathrm{~g}$ memberikan hasil yang paling optimum.

3. Penambahan ekstrak buah mengkudu ke dalam sabun transparan menurunkan aktivitas antioksidan pada mengkudu.

\section{Daftar Pustaka}

[1]. A. Chan, Formulasi Sediaan Sabun Mandi Padat dari Ekstrak Buah Apel sebagai Sabun Kecantikan Kulit, Jurnal Ilmiah Manuntung 2(1) (2016) 51-55.

[2]. A. Maulana, Pembuatan Sabun Transparan Aromaterapi Minyak Atsiri Akar Wangi, Skripsi, Universitas Pakuan, Indonesia, 2014.

[3]. A. Widyasanti, Pembuatan Sabun Padat Transparan menggunakan Minyak Kelapa Sawit dengan Penambahan Bahan Aktif Ekstrak Teh Putih, Jurnal Teknik Pertanian Lampung, 5(3) (2016) 125-130.

[4]. B. Risni Maripa, Pengaruh Konsentrasi $\mathrm{NaOH}$ terhadap Kualitas Sabun Padat dari Minyak Kelapa yang Ditambahkan Sari Bunga Mawar, Skripsi, Institut Keguruan dan Ilmu Pendidikan, Indonesia 2014.

[5]. C. Fachmi, Pengaruh Penambahan Gliserin dan Sukrosa terhadap Mutu Sabun Transparan, Skripsi, Institut Pertanian Bogor, Indonesia, 2008.

[6]. D. Fitriani, Karakteristik dan Aktivitas Antifungi Sabun Padat Transparan dengan Bahan Aktif Ekstrak Daun Buas-Buas, Jurnal Enviro Scientae, 13(1) (2017) 4046.

[7]. E. Nita Maharani Setyoningrum, Optimasi Formula Sabun Transparan dengan Fase Minyak Virgin Coconut Oil dan Surfaktan Cocoamidopropyl Betaine: Aplikasi Desain Faktorial, 2010, Skripsi, Universitas Sanata Dharma, Indonesia.

[8]. I. Anjani Roso Putri, dan Suhartiningsih, Pengaruh Penambahan Sari Aloe vera terhadap Sifat Fisik dan Masa Simpan Sediaan Sabun Transparan untuk Wajah, Jurnal Elektronik, 3(2) (2014) 23-29.

[9]. I Gusti Ayu Istri Praminingrat Aryadi, Pengaruh Ekstrak Daun Mengkudu terhadap Pertumbuhan Staphylococcus aureus sebagai Penyebab AbsesPeriodontal secara in vitro, Skripsi,Universitas Mahasaraswati, Indonesia, 2014.

[10]. I Nengah Juliana, Pemanfaatan Buah Mengkudu sebagai Absorben untuk Meningkatkan Mutu Minyak Jelantah, Jurnal Akademia Kimia, 4(4) (2015) 181188.

[11]. M. Sintia, Laporan Akhir Pembuatan Sabun Padat (Rasio Tallow- Minyak Kelapa - Minyak Jagung), 2016, tidak dipublikasikan.

[12]. Novitasari, Formula Pembuatan Sabun Transparan dengan Penambahan Kulit Pisang Ambon dan Sumbangsihnya pada Materi Pemanfaatan Limbah Organik di Kelas X SMA/MA, Skripsi, Universitas Islam Negeri Raden Fatah, Indonesia, 2016.

[13]. R. Febriyanti, Laporan Tugas Akhir Pengaruh Konsentrasi Asam Stearat Sebagai Basis Terhadap Sifat Fisik Sabun Transparan Minyak Jeruk Purut dengan Metode Destilasi, 2015, tidak dipublikasikan. 